\title{
Stage-Specific Initiation of Milk Synthesis in the Ovariectomized Pregnant Mouse
}

\author{
Chang Soo LEE and Senkiti SAKAI \\ Department of Animal Breeding, Faculty of Agriculture, \\ University of Tokyo, Bunkyo-ku, Tokyo 113
}

\begin{abstract}
Stage-specific initiation of milk synthesis was investigated in mice ovariectomized on days $7,9,11$ and 13 of pregnancy, and the lactogenic response of the mammary gland was monitored by using the synthesis of casein, lactose content and PRL binding as parameters. Pregnant mice ovariectomized on day 7 or 9 showed no increase in these parameters $24 \mathrm{~h}$ after operation. After day 11 of pregnancy, a clear response was induced by ovariectomy, characterized by a low level of casein synthesis, small amounts of lactose and PRL binding, which increased linearly in a time-dependent manner thereafter. These results indicate that pregnant mice after 11 days are able to initiate synthesis of casein and lactose in parallel. Mammary glands were cultured with insulin, cortisol and PRL. The mammary explants of pregnant mice at 7 and 9 days showed active synthesis of casein after a lag period of 2 days, suggesting that the mammary gland in early pregnancy is less sensitive to PRL, probably due to the absence of an increase in PRL binding after ovariectomy.
\end{abstract}

The mammary gland starts active synthesis and secretion of milk shortly after parturition, but milk synthesis is usually initiated during late pregnancy.

Ovariectomy during pregnancy can induce an increase in the mammary content of lactose from the basal level in mice and rats (Shinde et al., 1965; Kuhn, 1969a ; Simpson et al., 1973; Harigaya et al., 1980, 1982). This system allows us to determine the time-dependent change in mammary

Received February 24, 1987

To whom correspondence should be addressed.

Dr. SENKITI SAKAI

Department of Animal Breeding, Faculty of Agriculture, University of Tokyo, Yayoi 1-1-1, Bunkyo-ku, Tokyo 113, Japan

(Tel : 03-812-2111 ext. 5382) gland function at lactogenesis. In this study we examined the time or the stage of pregnancy at which the mammary gland is able to initiate casein- or lactose synthesis in response to ovariectomy. PRL is a lactogenic hormone, and binds to the mammary cell surface receptor. The responsiveness of the mammary gland to PRL was assessed by either the capacity for PRL binding or casein synthesis using the organcultured mammary gland.

\section{Materials and Methods}

\section{Chemicals and hormones}

PRL (NIAMDD-P-S15, $30.5 \mathrm{IU} / \mathrm{mg}$ ) was a gift from the NIAMDD, Bethesda, MD. SDSPAGE standard was supplied by Bio-Rad, Rich- 
mond, CA. Cortisol was obtained from Sigma, St Louis, MO. Porcine insulin was a gift from Novo Industri A/S, Bagsvaerd, Denmark. Medium 199 (M 199) and Earle's balanced salt (EBS) were from GIBCO, Grand Island, NY. En ${ }^{3}$ hance and ${ }^{14} \mathrm{C}$-amino acids mixture were from NEN, Boston, MA.

\section{Animals and ovariectomy}

ICR mice were obtained from Charles River Japan, Kanagawa. The day on which a vaginal plug was found was taken as day 0 of pregnancy. Ovariectomy was performed between 1000 and $1130 \mathrm{~h}$ on days $7,9,11$ and 13 of pregnancy. For the PRL binding and amino acid incorporation assays, a pair of the $3 \mathrm{rd}$ thoracic mammary tissues were sliced $(0.7 \mathrm{~mm}$ thickness) and used fresh. For lactose determination, the remaining mammary tissues were stored at $-20^{\circ} \mathrm{C}$ until use.

\section{Lactose determination}

The tissue $(300-400 \mathrm{mg}$ ) was homogenized in $3 \mathrm{ml}$ of distilled water. Lactose was extracted according to Harigaya et al. (1980). Following hydrolysis of lactose by $\beta$-galactosidase, $d$-glucose was determined as described below. For solution (A), $25 \mathrm{mg}$ glucose oxidase, $5 \mathrm{mg}$ peroxidase and $5 \mathrm{mg} o$-dianisidine were dissolved in $100 \mathrm{ml}$ of $0.1 \mathrm{M}$ phosphate buffer ( $\mathrm{pH}$ 7.0). For solution (B), $5 \mathrm{mg} \beta$-galactosidase was dissolved in $50 \mathrm{ml}$ of the same buffer. A mixture of $0.5 \mathrm{ml} \mathrm{sample}$ with $5 \mathrm{ml}$ of solution (A) and $0.5 \mathrm{ml}$ of solution (B) was incubated at $37^{\circ} \mathrm{C}$ for $60 \mathrm{~min}$. The optical density of the mixture was measured at $420 \mathrm{~nm}$, and the concentration of lactose was calculated by subtracting the value for the parallel incubation mixture, where solution (B) was replaced by phosphate buffer.

\section{$P R L$ binding assay}

A precise protocol for the iodination of PRL and the PRL binding assay has previously been described (Sakai et al., 1975, 1978). Specific radioactivity of ${ }^{125} \mathrm{I}-\mathrm{PRL}$ was about $80 \mu \mathrm{Ci} / \mu \mathrm{g}$. For a brief description of the PRL binding assay, the mammary slices $(10-15 \mathrm{mg})$ were incubated for $2 \mathrm{~h}$ in $1.5 \mathrm{ml}$ of $\mathrm{M} 199-0.25 \%$ BSA containing ${ }^{125} \mathrm{I}$-PRL $(450000 \mathrm{cpm})$ in the presence or absence of $5 \mu \mathrm{g}$ unlabeled PRL. Nonspecific binding was $50-60 \mathrm{cpm} / \mathrm{mg}$ tissue. For Scatchard analysis, the collagenase-dissociated mammray epithelial cells were used. The cell suspension $\left(0.4 \mathrm{ml}, 4 \times 10^{6}\right.$ cells), $10 \mu \mathrm{l}$ unlabeled PRL (2.5 to $80 \mathrm{ng}, 1 \mu \mathrm{g}$ ), and $90 \mu \mathrm{l}{ }^{125} \mathrm{I}-\mathrm{PRL}(100000 \mathrm{cpm})$ were combined and incubated for $2 \mathrm{~h}$. Nonspecific binding was about $600 \mathrm{cpm}$.

Organ culture and ${ }^{14} \mathrm{C}$-amino acid incorporation

The sliced mammary tissues were placed on floating lens paper in a $10 \mathrm{~cm}$ Falcon dish and incubated in $10 \mathrm{ml}$ of $\mathrm{M} 199$ containing $5 \mu \mathrm{g}$ insulin, $1 \mu \mathrm{g}$ cortisol and $5 \mu \mathrm{g}$ PRL per $\mathrm{ml}$ at $\begin{array}{llllll}37^{\circ} \mathrm{C} & \text { under } & 95 \% & \mathrm{O}_{2}-5 \% & \mathrm{CO}_{2} & \text {. The mammary }\end{array}$ tissues were collected every $24 \mathrm{~h}$. For the amino acid incorporation assay, the incubation medium consisted of $1 / 20(\mathrm{v} / \mathrm{v})$ M 199 and 19/20 EBS solution, and contained $1.5 \mu \mathrm{Ci} / \mathrm{ml}$ of ${ }^{14} \mathrm{C}$-amino acids. The mammary slices $(15-20 \mathrm{mg})$ were incubated in $1.5 \mathrm{ml}$ of the incubation medium for $3 \mathrm{~h}$ at $37^{\circ} \mathrm{C}$. Following incubation, the mammary tissues were homogenized in $1 \mathrm{ml} 150 \mathrm{mM} \mathrm{KCl} / 4$ $\mathrm{mM}$ sodium phosphate $/ 10 \mathrm{mM}$ imidasole ( $\mathrm{pH}$ 6.7). The homogenate was centrifuged at $12000 \mathrm{Xg}$ for $5 \mathrm{~min}$. Proteins in the supernatant were precipitated with $5 \%$ TCA. The precipitate was washed twice with 5\% TCA, once with ethanol, and air-dried. For sodium dodecyl sulfate-polyacrylamide gel electrophoresis (SDS-PAGE), the sample was denatured with SDS and dithiothreitol, and was subjected to the slab gel with a $12.5 \%$ acrylamide concentration. After SDS-PAGE, the gel was immersed in $E^{3}$ hance according to the manufacture's manual. The dried gel was exposed with Kodak X-Omat AR film at $-80^{\circ} \mathrm{C}$.

\section{Results}

Fig. 1 shows the results of PRL binding, lactose content and casein synthesis in the mammary gland $24 \mathrm{~h}$ after ovariectomy at different days of pregnancy. The amount of PRL binding was small in the intact control until day 13 of pregnancy. The mammary glands of mice ovariectomized on day 7 or 9 showed no increase in PRL binding. After day 11 of pregnancy, ovariectomy induced a 4.7- to 5.1-fold increase in PRL binding. The lactose content of the mammary gland of the intact control was very small until day 13 of pregnancy. Ovariectomy on day 7 or 9 did not induce 

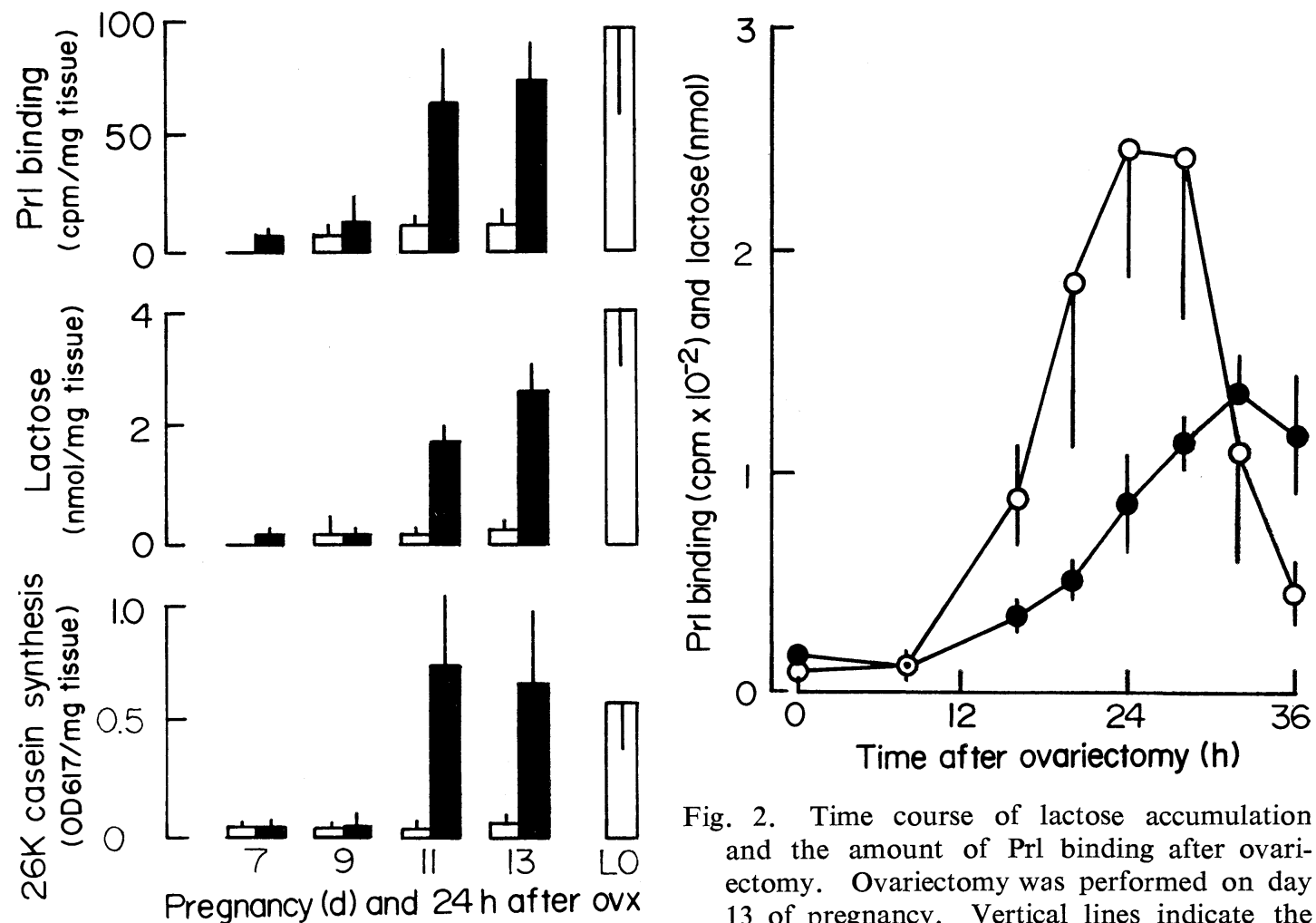

Fig. 2. Time course of lactose accumulation and the amount of Prl binding after ovariectomy. Ovariectomy was performed on day 13 of pregnancy. Vertical lines indicate the SD for 5 experiments. Lactose $(\bigcirc)$ and $\operatorname{Prl}$ binding (O).

Fig. 1. Changes in Prl binding, lactose and synthesis of the 26000 casein $24 \mathrm{~h}$ after ovariectomy (ovx). Days of pregnancy (open bars) and ovariectomy (black bars) are indicated in the Figure. LO is day 0 of lactation. Synthesis of the 26000 casein was examined by autoradiography and densitometry. Mean $\pm S D(n=4)$.

any change, but on day 11 or 13 it induced a significant increase in the lactose content. Synthesis of the 26000 casein was found only in pregnant mice ovariectomized on day 11 or 13 .

Fig. 2 shows the time-dependent changes in the amounts of PRL binding and lactose following ovariectomy of 13-day pregnant mice. The amounts of PRL binding and lactose were unchanged untill $8 \mathrm{~h}$ but increased almost linearly thereafter in a timedependent manner up to $32 \mathrm{~h}$ and $28 \mathrm{~h}$

after ovariectomy, respectively. The lactose content reached a maximum between 24$28 \mathrm{~h}$ after ovariectomy and decreased rapidly to a basal level during the $28-36 \mathrm{~h}$ period. The amount of PRL binding was the highest at $32 \mathrm{~h}$, a value 7.2-fold greater than the $0 \mathrm{~h}$ control. By Scatchard analysis, ovariectomy induced a $40 \%$ decrease in the $\mathrm{Kd}$ from $1.14 \pm 0.18 \mathrm{nM}$ to $0.71 \pm 0.14 \mathrm{nM}(\mathrm{M} \pm$ $\mathrm{SD}, \mathrm{n}=4$ ) during the $28 \mathrm{~h}$ period after operation. The number of PRL receptors per cell increased from $389 \pm 58$ at $0 \mathrm{~h}$ to $684 \pm 162$ at $20 \mathrm{~h}$, and to $986 \pm 112$ at $28 \mathrm{~h}$ after operation.

After ovariectomy, the mammary tissues in 13-day pregnant mice were collected every $6 \mathrm{~h}$ and ${ }^{14} \mathrm{C}$-amino acids incorporation into casein was examined by SDS-PAGE 


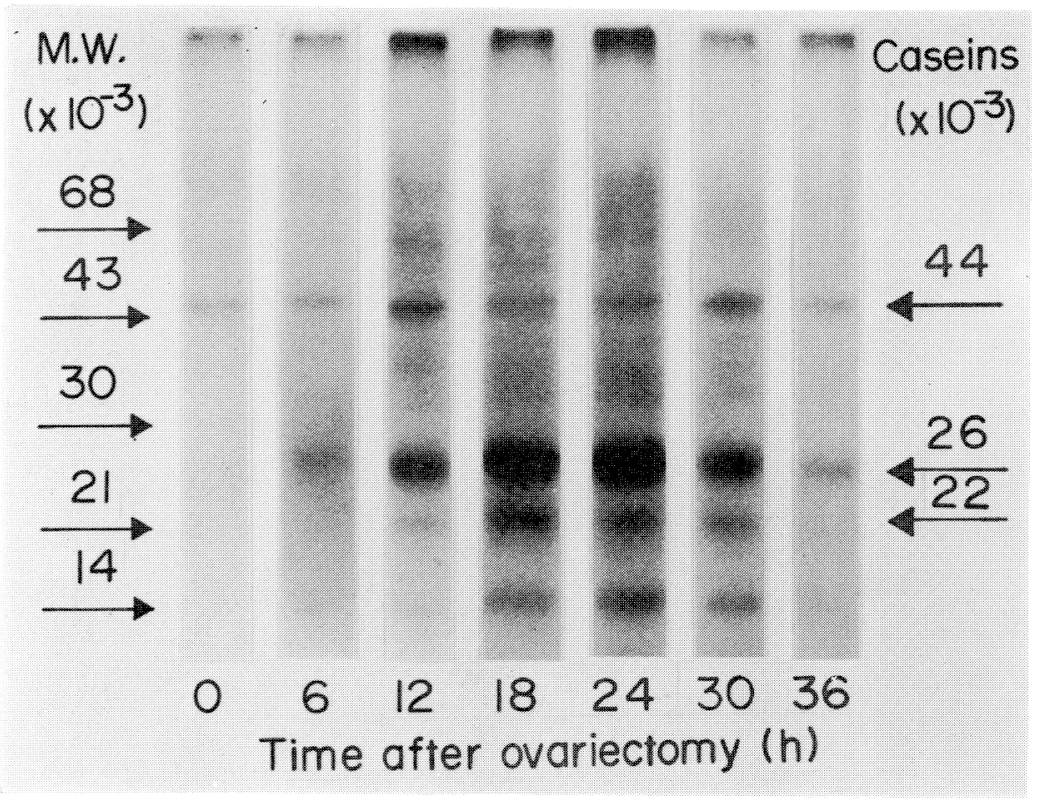

Fig. 3. Time-dependent incorporation of ${ }^{14} \mathrm{C}$ amino acids into casein after ovariectomy.

Mice were ovariectomized on day 13 of pregnancy. The extract from $1 \mathrm{mg}$ of tissue was applied to each lane. Arrows indicate the position of molecular weight markers (left) or of the components of mouse milk casein (right).
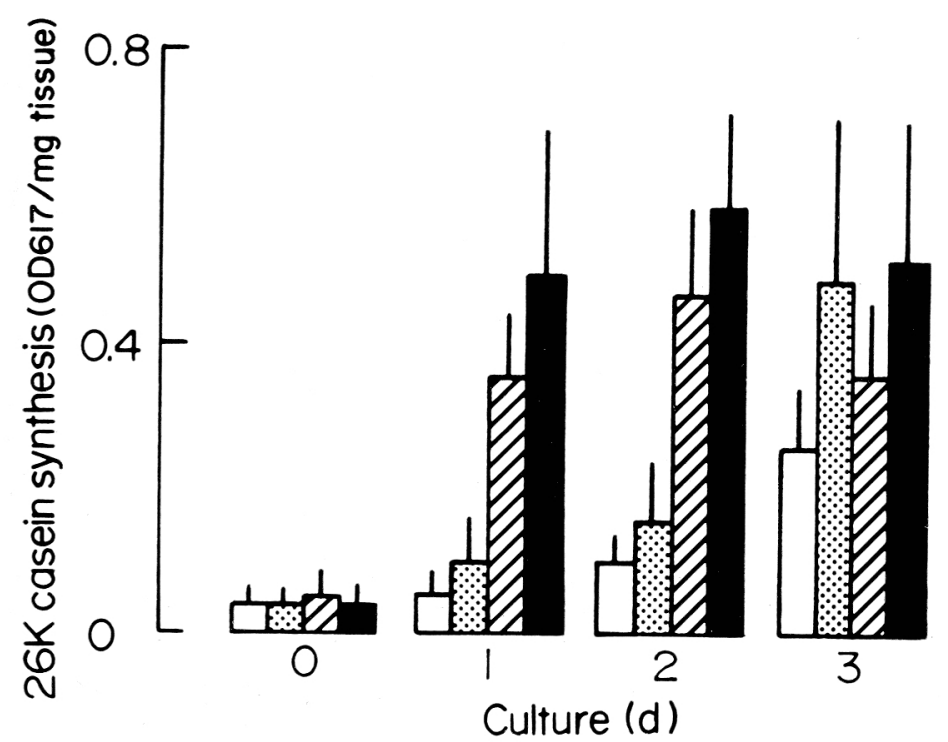

Fig. 4. Synthesis of 26000 casein by the organ-cultured mammary tissues. The day of pregnancy is shown as $7(\square), 9$ (圈), 11 $(\mathbb{Z})$, or 13 (ם). Mammary tissues were incubated with ${ }^{14} \mathrm{C}$-amino acids at the end of $0,1,2$, and 3-day culture. The optical density of the 26000 casein band in the autoradiogram was measured with a densitometer. Mean \pm SD (n $=3$ ).

(Fig. 3). The autoradiogram showed that radio-incorporated casein was separated into three bands with molecular weights of $44,000,26,000$ and 22,000. The band of 44000 casein was detected from $0 \mathrm{~h}$ to $36 \mathrm{~h}$. Synthesis of the 26000 casein, the most heavily labeled species, was influenced by the time after ovariectomy. A band of this type could scarcely be detected at $0 \mathrm{~h}$. The clear incorporation of ${ }^{14} \mathrm{C}$-amino acids took place $12 \mathrm{~h}$ after ovariectomy and this continued until $30 \mathrm{~h}$. The 22000 casein was less labeled than the 26000 casein but the time-dependency of synthesis was similar to 
that of the 26000 casein. Mammary tissues terminated active casein synthesis $36 \mathrm{~h}$ after ovariectomy. An unidentified protein with an apparent molecular weight of 14000 was synthesized in parallel with synthesis of the 26000 - or 22000 casein.

The mammary glands were cultured with insulin, cortisol and PRL and synthesis of the 26000 casein was examined in order to clear the responsiveness to PRL dependent on the day of pregnancy or the day of culture (Fig. 4). The mammary explants of pregnant mice at 7 or 9 days showed a low level of casein synthesis during the 2-day culture and active synthesis of the casein was found after a 3-day culture. The mammary explants of pregnant mice at 11 or 13 days showed active synthesis of casein during the 1-day culture and this continued for 3 days. In the absence of PRL, no casein synthesis was found (data not shown).

\section{Discussion}

The present experiments show that an increase in lactose could be induced first on day 12 of pregnancy in mice ovariectomized on day 11. This is similar to the finding in the rat (Shani et al., 1977). The induction of casein synthesis by ovariectomy was dependent upon the day of pregnancy or the time after operation, similar to that of lactose. The onset of lactose synthesis in this study is probably correlated with the appearence of $\alpha$-lactalbumin in the tissue, as reported by Palmiter (1969). Protein with a molecular weight of 14000 which is almost identical to that of $\alpha$-lactalbumin (Nagamatsu and Oka, 1980) appeared in the autoradiogram following ovariectomy in parallel with casein. By $24 \mathrm{~h}$ post operation, the levels of all parameters examined reached the same levels obtained in lactating mice on day 0 . Abortion occurred between $20 \mathrm{~h}$ and $24 \mathrm{~h}$ after ovariectomy. In the present experiments, active syntheses of casein and lactose were terminated at $36 \mathrm{~h}$ of operation, probably due to over-accumulation of milk in the mammary gland.

The appearance of lactose in the ovariectomized mouse or rat was suppressed by administration of progesterone (Kuhn, 1969b; Harigaya et al., 1982). The accumulation of casein mRNA which can be induced by PRL was suppressed by progesterone (Houdebine, 1976; Rosen et al., 1978). High levels of serum progesterone during pregnancy (McCormack and Greenwald, 1974; Murr et al., 1974) appear to inhibit the onset of casein- and lactose synthesis. However the mammary gland in mice at 7- and 9-day of pregnancy showed neither the onset of casein synthesis nor lactose synthesis after withdrawal of progesterone by ovariectomy. These fiindings suggest that the mammary gland until this stage is insensitive to PRL. Amounts of PRL binding were small in mice at 7- and 9 days of pregnancy and remained unchanged after ovariectomy. Invitro experiments showed that active synthesis of the casein in response to PRL was delay in the mammary gland of 7- or 9 day pregnancy as compared to 11 - or 13-day pregnant mice. After day 11 of pregnancy, ovariectomy induced an increase in the number of PRL receptors and a decrease in the $\mathrm{Kd}$ for PRL binding. Both changes lead to the binding of more PRLs to the mammary PRL receptors for the subsequent induction of milk synthesis.

Using ovariectomized mice, the mammary gland after day 11 of pregnancy showed different responses to PRL and is able to initiate casein- and lactose synthesis shortly after ovariectomy.

\section{References}

Harigaya, T., K. Kohmoto, K. Ota and A. Yokoyama (1980). Specific binding of prolactin to the mammary gland and lactose synthesis in pregnant rats after removal of ovaries or 
ovaries and adrenals. Endocrinol. Jpn. 27, 39-41.

Harigaya, T., S. Sakai, K. Kohmoto and Y. Shoda (1982). Influence of glucocorticoids on mammary prolactin receptors in pregnant mice after ovariectomy. J. Endocrinol. 94, 149-155.

Houdebine, L.-M. (1976) Effects of prolactin and progesterone on expression of casein genes. Eur. J. Biochem. 68, 219-225.

Kuhn, N. J. (1969a). Progesterone withdrawal as the lactogenic trigger in the rat. J. Endocrinol. 44, 39-54.

Kuhn, N. J. (1969b). Specificity of progesterone inhibition of lactogenesis. J. Endocrinol. 45, 615-616.

McCormack, J. T. and G. S. Greenwald (1974). Progesterone and estradiol-17 $\beta$ concentrations in the peripheral plasma during pregnancy in the mouse. J. Endocrinol. 62, 101-107.

Murr, S. M., G. H. Stabenfeldt, G. E. Bradford and I. I. Geschwind (1974). Plasma progesterone during pregnancy in the mouse. Endocrinology 94, 1209-1211.

Nagamatsu, Y. and T. Oka (1980). Purification and characterization of mouse $\alpha$-lactalbumin and preparation of its antibody. Biochem. J. 185, 227-237.

Palmiter, R. D. (1969). Hormonal induction and regulation of lactose synthetase in mouse mammary gland. Biochem. J. 113, 409-417.

Rosen, J. M., D. L. O'Neal, J. E. McHugh and J. P. Comstock (1978). Progesterone-mediated inhibition of casein mRNA and polysomal casein synthesis in the rat mammary gland during pregnancy. Biochemistry 17, 290-297.

Sakai, S., J. Enami, S. Nandi and M. R. Banerjee (1978). Prolactin receptors in dissociated mammary epithelial cells at different stage of development. Mol. Cell. Endocrinol. 12, 285-298.

Sakai, S., K. Kohmoto and T. Johke (1975). A receptor site for prolactin in lactating mouse mammary tissues. Endocrinol. Jpn. 22, 379387.

Shani, J., Ota, H. Tomogane and A. Yokoyama (1977). Induction of lactose synthesis in the mammary glands of pregnant rats by ovariectomy. J. Endocrinol. 72, 103-104.

Shinde, Y., K. Ota and A. Yokoyama (1965). Lactose content of mammary glands of pregnant rats near term: Effect of removal of ovary, placenta and foetus. J. Endocrinol. 31, 105114.

Simpson, A. A., M. H. W. Simpson and P. N. Kulkarni (1973). Prolactin production and lactogenensis in rats after ovariectomy in late pregnancy. J. Endocrinol. 57, 425-429. 